\title{
PELANGGARAN PRINSIP KESANTUNAN DALAM WACANA TUTUR BASUKI TJAHAJA PURNAMA (AHOK)
}

\author{
Fithratun Nisa \\ Dosen Pendidikan Bahasa dan Sastra Indonesia \\ STKIP PGRI Banjarmasin \\ Email: nisafithratun@yahoo.com
}

\begin{abstract}
ABSTRAK
Pelanggaran Prinsip Kesantunan dalam Wacana Tutur Basuki Tjahaja Purnama (Ahok). Penelitian ini bertujuan untuk mengungkapkan wujud dan fungsi pelanggaran prinsip kesantunan dalam tuturan Basuki Tjahaja Purnama (Ahok). Penelitian ini menggunakan pendekatan kualitatif dengan metode deskriptif. Sumber data dalam penelitian ini adalah video dari acara talk show(Kick Andy, Mata Najwa, dan Satu Jam lebih dekat), tuturan Ahok dalam acara talk show, dan dokumen tertulis berupa transkip tuturan-tuturan Basuki Tjahaja Purnama (Ahok). Pengumpulan data tersebut diperoleh dengan menggunakan metode simak dan diikuti dengan teknik lanjutan: teknik simak bebas libat cakap dan teknik catat. Hasil penelitian ini adalah sebagai berikut. Pertama, wujud pelanggaran prinsip kesantunan pada penelitian ini terungkap daripelanggaran prinsip kesantunan Leech yang meliputi: (1) pelanggaran maksim kebijaksanaan, (2) pelanggaran maksim penerimaan, (3) pelanggaran maksim kemurahan, (4) pelanggaran maksim kerendahan hati, (5) pelanggraan maksim kesetujuan, dan (6) pelanggaran maksim kesimpatian. Kedua, fungsi tuturan dari pelanggaran prinsip kesantunan pada wacana tutur Ahok, yaitu: (1) fungsi pelanggaran prinsip kesantunan dalam tindak tutur direktif, meliputi: perintah, permintaan, larangan, pertanyaan, dan persyaratan, (b) fungsi pelanggaran prinsip kesantunan dalam tindak tutur ekspresif, meliputi: mengejek, marah, frustasi, dan mengecam, dan (c) fumgsi pelanggaran prinsip kesantunan dalam tindak tutur asertif, meliputi: memberi alasan, memberitahu, menegaskan, menyatakan, minkan, menceritakan, dan bersikeras.
\end{abstract}

\section{PENDAHULUAN}

Bahasa merupakan alat komunikasi yang efektif dan memiliki peran penting bagi manusia. Sebagai alat komunikasi, bahasa digunakan oleh manusia untuk berinteraksi antarsesama dalam masyarakat karena manusia hidup dalam masyarakat. Oleh karena itu, setiap manusia harus dapat memahami maksud dan makna tuturan yang disampaikan oleh lawan tuturnya agar informasi yang diberikan dapat diterima dengan baik.

Pengungkapan maksud dan tujuan dalam peristiwa berbahasa berbedabeda. Pengungkapan dengan menggunakan bahasa yang sopan dan santun adalah cara penutur untuk menjalin hubungan sosial yang baik dengan lawan tutur. Sopan 
dan santun adalah memberi penghargaan atau menghormati orang yang diajak bicara, khususnya pendengar atau pembaca.

Kebanyakan para politikus dan pejabat tinggi negeri selalu terkesan menebarkan citra positif dan santun dalam setiap tuturannya. Namun, pejabat tinggi negeri yang menjadi objek dalam penelitian ini berbeda. Setiap tuturannya sering mengundang kontroversi, beliau adalah Gubernur DKI Jakarta; Basuki Tjahaja Purnama atau sering dipanggil Ahok. Beliau ini dikenal sebagai orang yang cara berbicaranya ceplas-ceplos, tegas, dan seringkali terdengar melanggar prinsip kesantunan. Tuturan Pak Ahok inilah yang mendorong peneliti untuk melakukan sebuah penelitian pragmatik dari segi kesantunan berbahasa.

Sejauh pengetahuan peneliti, penelitian tentang Bapak Basuki Tjahaja Purnama (Ahok) hanya ditemukan pada penelitian ilmu komunikasi saja. Kedua penelitian tersebut adalah "Analisis Isi Berita Kontroversi Basuki Tjahaja Purnamadalam Konteks Pengangkatan Gubernur DKI Jakarta Pada Surat Kabar Tribun Manado" oleh Almunaware, dkk (2015) dalam e-journal "Acta Diurna" dan "Strategi Personal Branding Joko Widodo (Jokowi) dan Basuki Tjahaja Purnama (Ahok)" oleh Sari (2013). Oleh karena itu, peneliti tertarik untuk mengkaji wacana tutur Basuki Tjahaja Purnama (Ahok) ini dari segi kebahasaan terutama aspek pragmatik. Aspek pragmatik yang dikhususkan peneliti dalam penelitian ini adalah pelanggaran prinsip kesantunan yang diperoleh dari tuturan Basuki Tjahaja Purnama (Ahok) sebagai pengisi atau bintang tamu dalam berbagai acara talk show yang banyak beredar dan dapat disimak maupun diunduh di youtube.

Tujuan dalam penelitian ini adalah untuk mengungkapkan wujud dan fungsi pelanggaran prinsip kesantunan dalam tuturan Basuki Tjahaja Purnama (Ahok). Manfaat penelitian ini adalah sebagai sumbangan wawasan atau pengetahuan untuk pengembangan kajian pragmatik. Khususnya pada kajian yang berkaitan dengan kesantunan. Secara praktis, manfaat penelitian ini adalah sebagai salah satu bahan untuk mempelajari kesantunan, pengajaran kesantunan, penyusunan buku teks, dan dapat dijadikan sebagai acuan bagi penelitian selanjutnya, khususnya pada bidang kajian yang sejenis.

Grice dalam Rustono (1999:66) mengungkapkan bahwa prinsip kesantunan adalah prinsip yang berkenaan dengan aturan tentang hal-hal yang bersifat sosial, estetis, dan moral dalam bertindak tutur. Sedangkan Lakoff dalam Eelen menyatakan bahwa kesantunan berbahasa merupakan salah satu wujud pragmatik, berbahasa sebagai bidang kajian fungsional bahasa yang dapat dikaji secara konvensional atau ada kesepakatan makna yang ditentukan oleh sejumlah elemen wacana. Kesantunan sebagai sistem, mendukung interaksi tersebut dengan meminimalkan potensi dankonfrontasi yang terjadi pada semua hubungan manusia.

Lakoff dalam Jumadi (2010: 74) mendefinisikan kesantunan sebagai sistem hubungan interpersonal yang dirancang untuk mendukung interaksi dengan meminimalkan potensi konflik dan konfrontasi yang terjadi pada semua hubungan sosial antara penutur dengan mitra tutur dengan berusaha menghindari konflik antara penutur dengan mitra tutur, sehingga terjalin hubungan sosial yang baik.

Lakoff dalam Chaer (2010: 46) mengatakan jika tuturan ingin terdengar santun di telinga pendengar atau lawan tutur kita, ada tiga buah kaidah yang harus dipatuhi. Ketiga buah kaidah kesantunan itu adalah formalitas (formality), 
ketidaktegasan (hesitancy) dan persamaan atau kesekawanan (equality or camaraderie). Ketiga kaidah itu apabila dijabarkan, 1) formalitas (formality), berarti jangan memaksa atau angkuh (aloof); 2) ketidaktegasan(hesitancy), berarti buatlah sedemikian rupa sehingga lawan tutur dapat menentukan pilihan (option) dan 3) persamaan atau kesekawanan(equality or camaraderie), berarti bertindaklah seolah-olah Anda dan lawan tutur Anda menjadi sama.

Kesantunan dikembangkan berdasarkan parameter skalauntung-rugi (cost benefit-scale). Semakin menguntungkan lawan tutur, tuturan yang dibuat semakin santun, demikian juga sebaliknya. Salah satu indikator kesantunan adalah dengan menyusun ketidaklangsungan tuturan (Leech; 2011).

Teori kesantunan yang diungkapkan oleh Leech (2011) berdasarkan prinsip kesantunan (politeness principles) yang dijabarkan menjadi maksim. Keenam maksim itu adalah:

(1) Kebijaksanaan (tact maxim), menggariskan bahwa setiap peserta pertuturan harus meminimalkan kerugian orang lain dan memaksimalkan keuntungan orang lain.

(2) Penerimaan (generosity maxim) menghendaki setiap peserta pertuturan untuk memaksimalkan kerugian bagi diri sendiri dan meminimalkan keuntungan diri sendiri.

(3) Kemurahan (approbation maxim) menuntut setiap peserta pertuturan untuk memaksimalkan rasa hormat kepada orang lain dan meminimalkan rasa tidak hormat kepada orang lain.

(4) Kerendahan hati (modesty maxim) menuntut setiap peserta pertuturan untuk memaksimalkan ketidakhormatan pada diri sendiri dan meminimalkan rasa hormat pada diri sendiri.

(5) Kecocokan/kesetujuan (agreement maxim) menghendaki agar setiap penutur dan lawan tutur memaksimalkan kesetujuan di antara mereka dan meminimalkan ketidaksetujuan di antara mereka.

(6) Kesimpatian (sympathy maxim) mengharuskan semua peserta pertuturan untuk memaksimalkan rasa simpati dan meminimalkan rasa antipati kepada lawan tuturnya. Jika lawan tutur mendapat kesulitan atau musibah penutur sudah sepantasnya menyampaikan rasa duka atau bela sungkawa sebagai tanda kesimpatian.

Chaer (2010: 61) memberikan kesimpulan terhadap teori kesantunan Leech, yaitu sebagai berikut.

a) maksim kebijaksanaan, maksim penerimaan, maksim kemurahan hati dan maksim kerendahan hati adalah maksim yang berhubungan dengan keuntungan atau kerugian diri sendiri dan orang lain.

b) maksim kecocokan dan maksim kesimpatian adalah maksim yang berhubungan dengan penilaian buruk atau naik penutur terhadap dirinya sendiri atau orang lain.

c) maksim kebijaksanaan dan maksim kemurahan hati adalah maksim yang berpusat pada orang lain (other contred maxim).

d) maksim penerimaan dan kerendahan hati adalah maksim yang berpusat pada diri sendiri (self centred maxim). 
Hubungannya dengan fungsi pelanggaran prinsip kesantunan, bagian berikut ini akan diuraikan tentang fungsi tindak tutur. Searle (Leech, 164: 2011) membagi tindak tutur menjadi lima, yaitu tindak tutur asertif, tindak tutur direktif, tindak tutur komisif, tindak tutur ekspresif, dan tindak tutur ekspresif. Pada penelitian ini, fungsi pelanggaran prinsip kesantunan yang diambil dari teori Searle difokuskan pada tiga fungsi tuturan saja, yaitu fungsi tindak tutur direktif, fungsi tindak tutur ekspresif, dan fungsi tindak tutur asertif.Pertama, Leech (2011: 164) mengungkapkan bahwa tindak tutur direktif adalah tindak tutur yang bertujuan untuk menghasilkan suatu efek berupa tindakan yang dilakukan oleh petutur agar melakukan sesuatu. Tindak tutur jenis ini berupa memerintah, memesan, memohon, menuntut, dan memberi nasihat.Kedua, tindak tutur ekspresif diartikan sebagai tindak tutur yang berfungsi untuk mengekspresikan perasaan dan sikap seseorang terhadap keadaan atau sesuatu. Searle (Jumadi, 2010:66) menjelaskan bahwa fokus utama dalam tindak tutur jenis ini adalah untuk mengungkapkan keadaan psikologis seseorang yang ditetapkan oleh kondisi kejujuran tentang keadaan dalam isi proposisi. Tindak ekspresif ini mencakup tindakan mengucapkan rasa terimakasih, mengucapkan selamat, mengucapkan belasungkawa, menyesalkan, permintaan maaf, dan mengecam.Terakhir, tindak tutur asertif adalah tindak tutur yang berfungsi untuk memberitahu orang-orang mengenai sesuatu (Searle dalam Jumadi, 2010:66). Kaitannya dengan fungsi bahasa, Halliday (Jumadi, 2010:67) mengemukakan bahwa tindak tutur asertif selaras dengan fungsi bahasa untuk informatif.Searle (Jumadi, 2010:67) menyatakan bahwa tindak tutur ini mencakup tindakan mempertahankan, menyatakan, dan melaporkan. Selain itu, Verschueren (Jumadi, 2010:67) menyatakan bahwa tindak tutur asertif ini mencakup tindakan menegaskan, memberikan alasan, memberitahukan, memperkirakan, menebak, bersikeras,menyatakan atau mengajukan, memberikan kesaksian di bawah sumpah, dan menceritakan.

Leech (2011: 20) mengartikan konteks sebagai suatu pengetahuan latar belakang yang sama-sama dimiliki oleh penutur dan petutur yang membantu petutur untuk menafsirkan makna tuturan. Hubungannya dalam pragmatik, Kridalaksana (2008: 134) menyebutkan bahwa konteks merupakan aspek-aspek lingkungan fisik atau sosial yang kait-mengait dengan ujaran tertentu. Menurutnya konteks juga diartikan sebagai pengetahuan yang sama-sama dimiliki pembicara dan pendengar sehingga pendengar paham terhadap apa yang dimaksud pembicara.Berkaitan dengan wacana, Halliday dan Hasan (Rani, 2004: 188) menyebutkan bahwa konteks wacana adalah teks yang menyertai teks lain. Menurut mereka, pengertian dalam hal menyertai teks itu tidak hanya yang dilisankan dan dituliskan, tetapi juga kejadian-kejadian nirkata (nonverbal) lainnya. Jadi, konteks adalah aspek-aspek lingkungan fisik atau sosial yang menyertai pembicaraan antara penutur dan petutur yang digunakan sebagai acuan untuk menafsirkan makna yang dimaksud penutur (pembicara).

Gelar wicara (bahasa Inggris: talk show; chat show) adalah suatu jenis acara televisi atau radio yang berupa perbincangan atau diskusi seorang atau sekelompok orang "tamu" tentang suatu topik tertentu (atau beragam topik) dengan dipandu oleh pemandu gelar wicara. Tamu dalam suatu gelar wicara biasanya terdiri dari orang-orang yang telah mempelajari atau memiliki pengalaman luas yang terkait dengan isu yang sedang diperbincangkan. Suatu 
gelar wicara bisa dibawakan dengan gaya formal maupun santai dan kadang dapat menerima telepon berupa pertanyaan atau tanggapan dari pemirsa atau orang di luar studio (Wikipedia). Ariestari (2013: 9) mengatakan bahwa talk show merupakan program televisi atau radio yang menghadirkan seseorang ataupun grup berkumpul bersama untuk mendiskusikan berbagai hal topik dengan suasana santai tapi serius dan dipandu oleh seorang moderator. Kadangkala, menghadirkan tamu berkelompok yang ingin mempelajari berbagai pengalaman hebat. Di lain hal juga, seorang tamu dihadirkan oleh moderator untuk berbagi pengalaman. Acara Talkshow biasanya diikuti dengan menerima telepon dari para pendengar atau penonton yang berada di rumah, mobil, ataupun ditempat lain. Jadi, dapat disimpulkan bahwa talk show termasuk dalam salah satu program acara yang diadakan di sebuah televisi atau radio. Talk show atau gelar wicara merupakan sebuah acara yang menghadirkan seseorang atau sekelompok orang sebagai narasumber untuk berbagi informasi maupun pengalaman baik secara formal maupun santai. Acara ini kadang-kadang juga melibatkan orang yang berada di luar studio untuk memberikan tanggapan, pertanyaan, maupun berbagi cerita.

\section{METODE}

Metode yang digunakan pada penelitian ini adalah metode deskriptif. Metode deskriptif digunakan pada penelitian ini karena digunakan untuk mendeskripsikan tuturan-tuturan Basuki Tjahaja Purnama (Ahok) yang melanggar prinsip kesantunan, yaitu data yang berupa pelanggaran prinsip kesantunan dan fungsinya dalam berbagai acara talk show. Penelitian ini menggunakan jenis penelitian pragmatik. Jenis penelitian pragmatik dipilih peneliti karena ini adalah penelitian yang termasuk dalam kajian studi pragmatik yang bertujuan untuk mengkaji wujud dan fungsi tuturan yang melanggar prinsip kesantunan. Jenis penelitian ini digunakan untuk mengkaji tuturan-tuturan Basuki Thajaja Purnama (Ahok)yang melanggar prinsip kesantunan beserta fungsinya.

Sumber data pada penelitian ini terdapat dalam video acara talk show ketika Basuki Tjahaja Purnama (Ahok) sebagai bintang tamu. Sumber datanya berupa video dari acara Kick Andy (05 Februari 2016) yang berdurasi 60 menit, Mata Najwa (16 Maret 2016) yang berdurasi 60 menit, dan Satu Jam lebih dekat (28 Desember 2014) yang berdurasi 41 menit, dan dokumen tertulis yang merupakan hasil transkip dari tuturan-tuturan Basuki Tjahaja Purnama (Ahok) bersama pembawa acara dalam beberapa video.

Teknik yang digunakan dalam pengumpulan data pada penelitian ini adalah dengan menggunakan metode simak. Mahsun (2007:92) menamakannya metode simak karena untuk memperoleh data dilakukan dengan cara menyimak penggunaan bahasa baik secara lisan maupun tulisan. Metode ini memiliki teknik dasar yang berwujud teknik sadap. Dalam praktik selanjutnya, teknik sadap ini diikuti dengan teknik lanjutan yang berupa teknik simak libat cakap, simak bebas libat cakap, catat, dan teknik rekam. Pada penelitian ini peneliti menggunakan metode simak dan diikuti dengan teknik lanjutan: teknik simak bebas libat cakap dan teknik catat.

a) Metode simak maksudnya si peneliti memperoleh tuturan-tuturan Basuki Tjahaja Purnama (Ahok) dalam berbagai acara talk show dengan cara menyimak percakapan yang disampaikan secara lisan dalam acara tersebut. 
b) Simak bebas libat cakap maksudnya si peneliti hanya mengamati penggunaan bahasa pada tuturan-turan Basuki Tjahaja Purnama (Ahok) dalam berbagai acara talk show, tetapi tidakikut terlibat dalam peristiwa tuturan pada acara tersebut.

c) Teknik catat maksudnya si peneliti melakukan pencatatan tuturan-turan Basuki Tjahaja Purnama (Ahok) dalam berbagai acara talk show ketika menerapkan metode simak.

\section{HASIL DAN PEMBAHASAN}

\section{Wujud Pelanggaran Prinsip Kesantunan dalam Tuturan Basuki Tjahaja Purnama (Ahok)}

Kesantunan dipandang sebagai aturan perilaku antara masyarakat sosial dalam bertutur sebagai syarat terwujudnya kesopansantunan dalam interaksi sosial. Teori kesantunan berdasarkan prinsip kesantunan (politeness principles) yang dijabarkan menjadi beberapa maksim. Jadi, dalam penelitian ini mengungkap wujud tuturan Ahok yang melanggar prinsip kesantunan. Prinsip ini terbagi menjadi enam maksim, yaitu: maksim (1) kebijaksanaan (tact maxim), (2) penerimaan (generosity maxim), (3) kemurahan (approbation maxim), (4) kerendahan hati (modesty maxim), (5) kesetujuan (agreement maxim), (6) kesimpatian (sympathy maxim).

\section{Wujud Pelanggaran Maksim Kebijaksanaan}

Konteks: Andy F. Noya menanyakan tentang Ahok yang pernah mengusulkan $\mathrm{H}$. Lulung yang pernah berseteru dengannya agar mencalonkan diri sebagai Gubernur menyaingi dirinya.

Andy F. Noya : "Anda pernah mengusulkan secara terbuka agar $\mathrm{H}$. Lulung ikut mencalonkan diri menjadi Gubernur DKI. Anda serius atau main-main?" (1)

Ahok : "Ya, serius! Masing-masing orang kan ada pendukung. Masing-masing orang kan merasa pantas dan layak menjadi Gubernur DKI mengganti saya. Nah, kalau dia nggak ikut kan kasian juga kalau seumur hidup tetap merasa dia bisa tapi nggak ada kesempatan untuk itu." (2)

(Sumber: Kick Andy, 05 Februari 2016)

Tuturan Ahok tersebut merupakan bentuk pelanggaran prinsip kesantunan dalam maksim kebijaksanaan. Pelanggaran maksim tersebut terdapat pada kutipan (2) yang dituturkan oleh Ahok, yaitu"Ya, serius! Masing-masing orang kan ada pendukung. Masing-masing orang kan merasa pantas dan layak menjadi Gubernur DKI mengganti saya. Nah, kalau dia nggak ikut kan kasian juga kalau seumur hidup tetap merasa dia bisa tapi nggak ada kesempatan untuk itu.".Tuturan yang disampaikan oleh Ahok tersebut tidak memberikan keuntungan bagiH. Lulung. Tuturan Ahok justru merugikan H. Lulung yang dinilainya hanya merasa lebih baik dari Ahok tetapitidak mampu membuktikan menjadi Gubernur menggantikan dirinya yang sudah terbukti baik memimpin Jakarta selama ini. Hal 
ini tidak sesuai dengan penerapan maksim kebijaksanaan, yaitu memberikan keuntungan yang maksimal kepada orang lain dan meminimalkan kerugian bagi orang lain.

\section{Wujud Pelanggaran Maksim Penerimaan}

Konteks: Andy F. Noya menanyakan tanggapan Ahok terhadap orang-orang yang tidak menyukai Ahok menganggap dia adalah orang yang tidak berperikemanusiaan.

Andy F. Noya : "Anda dianggap tidak manusiawi, bagaimana?" (1)

Ahok : "Tidak manusiawi kan itu kata dia. Yang bilang manusiawi kan banyak. Yang penting 50\%+1, itu saja patokannya." (2)

(Sumber: Kick Andy, 05 Februari 2016)

Tuturan Ahok tersebut merupakan bentuk pelanggaran prinsip kesantunan dalam maksim penerimaan. Pada wacana tersebut terdapat pelanggaran maksim penerimaan yang dituturkan oleh Ahok, yaitu pada tuturan "Tidak manusiawi kan kata dia. Yang bilang manusiawi kan banyak. Yang penting 50\%+1, itu saja patokannya.". Tuturan Ahok tersebut merupakan pelanggaran maksim penerimaan karena dia tidak memaksimalkan kerugian bagi dirinya sendiri. Namun, dia justru memaksimalkan keuntungan bagi dirinya sendiri, yaitu yang penting minimal ada 50\%+1 warga Jakarta mendukungnya selebihnya dia tidak pedulikan. Hal ini tidak sesuai dengan penerapan maksim penerimaan yang menghendaki setiap peserta pertuturan untuk memaksimalkan kerugian bagi diri sendiri dan meminimalkan keuntungan diri sendiri

\section{Wujud Pelanggaran Maksim Kemurahan}

Konteks:

Najwa Shihab : "Anda tadi bilang tidak terganggu dengan Sumber Waras. Tapi, baru saya tanya begitu nada Anda tinggi banget, Pak Ahok. Berrti, iya terganggu?" (1)

Ahok : : "Aku keki aja sama orang bodoh-bodoh seperti itu." (2)

(Sumber: Mata Najwa, 16 Maret 2016)

Tuturan Ahok pada kutipan di atas melanggar prinsip kesantunan, yaitu maksim kemurahan. Maksim kemurahan (approbation maxim) menuntut setiap peserta pertuturan untuk memaksimalkan rasa hormat kepada orang lain dan meminimalkan rasa tidak hormat kepada orang lain. Dari jawaban Ahok di atas, terlihat bahwa Ahok tidak memaksimalkan rasa hormat dan meminimalkan rasa tidak hormat kepada pihak FPI.Hal ini terlihat pada tuturan "Aku keki aja sama orang bodoh-bodoh seperti itu." yang disampaikan oleh Ahok. Tuturan Ahok menggunakan sebutan "orang bodoh" merupakan pelanggaran maksim kemurahan, karena Ahok tidak memaksimalkan rasa hormat kepada FPI dan justru memaksimalkan rasa tidak hormatnya kepada FPI. 


\section{Wujud Pelanggaran Maksim Kerendahan Hati}

Konteks: Ahok diwawancara tentang tanggapannya terhadap orang yang tidak menyukainya menjadi Gubernur DKI.

Andy F. Noya : "Sebagian orang memuji Anda, tetapi banyak juga yang memaki-maki Anda. Nah, menghadapi orang yang memakimaki Anda ini sikap Anda bagaimana?" (1)

Ahok : "Santai saja! Saya jadi Gubernur DKI cuma perlu 50\% suka kok!"'(2)

(Sumber: Kick Andy, 05 Februari 2016)

Ditinjau dari prinsip kesantunan dalam sebuah percakapan, jawaban Ahok melanggar prinsip tersebut. Tuturan Ahok "Santai saja! Saya jadi Gubernur DKI cuma perlu 50\% suka kok!" telah melanggar maksim kerendahan hati. Berdasarkan jawaban Ahok tersebut, terlihat bahwa Ahok tidak memaksimalkan rasa hormat terhadap orang yang suka memaki dirinya dan lebih memaksimalkan rasa hormat pada dirinya sebagai seorang Gubernur.

\section{Wujud Pelanggaran Maksim Kesetujuan}

Konteks: Andy F. Noya menyarankan Ahok agar berubah lebih santun.

Andy F. Noya : "Ngomong-ngomong soal Anda melawan arus, apa Anda nggak bisa berubah, ya? Mungkin lemah lembut, mungkin lebih santun?" (1)

Ahok : "Susah, loh. Capek, kalau memerankan jadi orang lain. Kalau kita mau main drama, film kan mesti latihan sebulan untuk pentas sejam kalau tiap hari harus pura-pura, ya capek dong. Latihanya berapa jam?" (2)

(Sumber: Kick Andy, 05 Februari 2016)

Dalam wacana tuturan Ahok di atas terdapat pelanggaran maksim kesetujuan atau kecocokan. Hal ini terlihat dari tuturan Ahok yang tidak memaksimalkan kesetujuan terhadap saran dari Andy F. Noya. Tuturan Ahok "Susah, loh. Capek, kalau memerankan jadi orang lain. Kalau kita mau main drama, film kan mesti latihan sebulan untuk pentas sejam kalau tiap hari harus pura-pura, ya capek dong. Latihanya berapa jam?" merupakan bentuk penolakan atau ketidaksetujuan terhadap saran Andy F. Noya. Dengan demikian, tuturan Ahok tersebut telah melanggar prinsip kesantunan dari maksim kesetujuan.

\section{Wujud Pelanggaran Maksim Kesimpatian}

Konteks: Presenter acara "Satu Jam Lebih Dekat" menanyakan tanggapan Ahok mengenai FPI yang tidak mendukung dirinya sebagai gubernur.

Indy Rahmawati : "Jadi, kalau misalnya nih ada judul berita yang menuliskan 'Ahok siap gantikan Jokowi. FPI: Ahok arogan' gimana, pak?” (1) 
Ahok

: "Ya, memang gua arogan. Lu kayak baru tau aja gua arogan. Kasian banget!" (2)

(Sumber: Satu Jam Lebih Dekat, 28 Desember 2014)

Tuturan Ahok pada kutipan di atas melanggar prinsip kesantunan, yaitu maksim kesimpatian. Maksim ini berhubungan dengan penilaian buruk atau baik penutur terhadap dirinya sendiri atau orang lain. Dari jawaban ekspresif Ahok di atas, terlihat bahwa Ahok tidak memaksimalkan rasa simpati dan meminimalkan rasa antipati kepada pihak FPI.Rasa simpati yang sangat minimal dan rasa antipati yang maksimal terhadap FPI terlihat dengan penggunaan kata "Lu" yang digunakan Ahok untuk merespon ketidaksukaan pihak FPI kepada dirinya. Penggunaan kata ganti orang kedua "Lu" yang digunakan Ahok dinilai tidak sopan dan sama sekali tidak menunjukkan rasa hormat dan simpati kepada FPI. Kata "Kesian banget" yang dituturkan Ahok pada kutipan tuturan tersebut juga merupakan wujud rasa antipati dan melanggar maksim kesimpatian terhadap pihak FPI.

\section{Fungsi Pelanggaran Prinsip Kesantunan dalam Tindak Tutur Direktif}

Konteks: Andy F. Noya meminta tanggapan Ahong tentang larangannya kepada orang yang unjuk rasa di sembarang tempat.

Andy F. Noya : "Ada sedikit yang masih mengganggu, ya. Itu, waktu itu Anda melarang orang unjuk rasa di sembarang tempat di Jakarta. Anda bilang ada tiga tempat, ya.. di situ! Walaupun kemudian Anda koreksi atau revisi. Tetapi ide untuk melarag orang untuk unjuk rasa di sembarang tempat ini dasarnya apa?" (1)

Ahok : "Macet! Lagipula kan Cuma mau teriak-teriak di depan presiden. Ya sudah, di Monas aja sudah. Rapi, gitu loh! Tapi jangan di Bundaran HI, dong! Macet di Bundaran HI. Makanya saya lagi nego. Sudah nulis surat kepada pemerintah Inggris. Kita mau beli bekas Dubes Inggris. Nah saya mau bikin taman. Lu mau demo, demo di situ lah! Belagu amat!" (2)

(Sumber: Kick Andy, 05 Februari 2016)

Fungsi pelanggaran prinsip kesantunan pada tuturan (2) yang dituturkan oleh Ahok termasuk dalam fungsi direktif. Fungsi direktif dalam tuturan Ahok tersebut adalah memberi perintah dan larangan. Tuturan "M acet! Lagipula kan Cuma mau teriak-teriak di depan presiden. Ya sudah, di Monas aja sudah. Rapi, gitu loh! Tapi jangan di Bundaran HI, dong! Macet di Bundaran HI. Makanya saya lagi nego. Sudah nulis surat kepada pemerintah Inggris. Kita mau beli bekas Dubes Inggris. Nah saya mau bikin taman. Lu mau demo, demo di situ lah! Belagu amat!" yang dituturkan Ahok adalah memberikan perintah dan larangan kepada para pengunjuk rasa agar melakukan demo di Monas saja, jangan disembarang tempat karena dapat menyebabkan kemacetan.

\section{Fungsi Pelanggaran Prinsip Kesantunan dalam Tindak Tutur Ekspresif}

Konteks: Presenter acara "Satu Jam Lebih Dekat" meminta tanggapan Ahok ketika diperlihatkan peta negara Kanada. 
Indy Rahmawati : "Pernah Pak Ahok ingin ke sana? Kenapa, Pak?"

Ahok
: "Karena saya frustasi, habis mau tabok pejabat jadi pabrik saya tutup. Karena kurang ajar, ngeyel pejabatnya. Dia bilang gini, nasib pabrik kamu tergantung saya. Kalau saya bilang tutup, tutup. Saya bilang enak aja, nasib pabrik saya tergantung kamu, tergantung saya dong mau tutup atau enggak. Dia pikir saya takut bangkut. Saya nggak peduli, minimal dia saya tabok aja. Tapi dia sudah keburu lari." (2)

(Sumber: Satu Jam Lebih Dekat, 28 Desember 2014)

Fungsi tuturan akibat pelanggaran prinsip kesantunan yang dituturkan oleh Ahok tersebut termasuk dalam fungsi ekspresif. Fungsi ekspresif dalam tuturan Ahok tersebut adalah sebagai ekspresi dari kemarahan dan frustasi. Kutipan (2) dari tuturan Ahok tersebut memiliki fungsi untuk mengungkapkan rasa marah dan frustasinya kepada pejabat yang ingin menutup pabriknya.

\section{Fungsi Pelanggaran Prinsip Kesantunan dalam Tindak Tutur Direktif}

Konteks: Ahok diminta untuk menanggapi tentang keberaniannya melakukan pertaruhan politik untuk maju menjadi calon gubernur lewat jalur independen.

Najwa Shihab : "Tetapi bererti pengalaman politik Anda, pengalaman bertaruh politik Anda sudah sangat banyak". (1)
Ahok : : "Saya jagoan satu Indonesia soal bertaruh, kalau ngomong sombong." (2)
Najwa Shihab : "PD banget Pak Ahok." (3)

(Sumber: Mata Najwa, 16 Maret 2016)

Fungsi tuturan akibat dari pelanggaran prinsip kesantunan yang dituturkan Ahok pada kutipan (2) termasuk dalam fungsi asertif. Fungsi asertif dalam tuturan tersebut adalah memiliki fungsi untuk memberitahu. Tuturan "Saya jagoan satu Indonesia soal bertaruh, kalau ngomong sombong." Yang diungkapkan oleh Ahok memiliki fungsi untuk memberitahu kepada lawan tutur bahwa dia memang orang yang sangat berani danhebat dalam mengambil keputusan yang mempertaruhkan posisinya.

\section{SIMPULAN DAN SARAN}

Simpulan

Berdasarkan hasil dan pembahasan di atas, diperoleh kesimpulan bahwa terdapat pelanggaran prinsip kesantunan dalam wacana tutur Basuki Tjahaja Purnama (Ahok), yaitu pelanggaran maksim kebijaksanaan, pelanggaran maksim penerimaan, pelanggaran maksim kemurahan,pelanggaran maksim kerendahan hati, pelanggraan maksim kesetujuan, dan pelanggaran maksim kesimpatian.Selanjutnya, fungsi tuturan dari pelanggaran prinsip kesantunan yang 
terungkaap pada wacana tutur Ahok, yaitu: fungsi direktif, fungsi ekspresif, dan fumgsi asertif.

\section{Saran}

Saran dari peneliti adalah agar hasil penelitian ini dapat dijadikan sumber informasi bagi penelitian pragmatik, khususnya kesantunan. Teori yang digunakan untuk mengungkap pelanggaran prinsip kesantunan dalam penelitian ini adalah tuturan yang melanggar teori prinsip kesantunan dari Leech. Oleh karena itu, bagi para peneliti selanjutnya yang tertarik untuk meneliti tentang kesantunan diharapkan untuk mengembangkan penelitian dengan metode dan teori yang lainnya.Bagi peneliti selanjutnya, hendaknya menggunakan objek penelitian yang berbeda agar dapat mengembangkan hasil penelitian kebahasaan. Talkshow sebagai objek penelitian ini dapat dikembangkan dengan objek penelitian yang berbeda, seperti pada film, pada percakapan sehari-hari, dan lain-lain.

\section{DAFTAR RUJUKAN}

Almunaware, dkk. 2015. “Analisis Isi Berita Kontroversi Basuki Tjahaja Purnama

dalam Konteks Pengangkatan Gubernur DKI Jakarta Pada Surat Kabar Tribun Manado". E-Jounal "Acta Diurna”. Vol. IV, No. 3, 1-8, (online), (http://ejournal.unsrat.ac.id/ index. php/ actadiurna/ article/ view/ 7707. html, diakses 10 April 2016).

Ariestari, A.H. 2013. Hubungan Terpaan Talk Show "DR. OZ Indonesia" di TRANS TV dengan Gaya Hidup Masyarakatdalam Menjaga Kesehatan (Studi Korelasional Hubungan Terpaan Talk Show "DR. OZ Indonesia" di TRANS TV Dengan Gaya Hidup Masyarakat Dalam Menjaga Kesehatan di Surabaya). Surabaya: Universitas Pembangunan Nasional "Veteran".

Chaer, A. 2010. Kesantunan Berbahasa. Jakarta: Rineka Cipta.

Jumadi. 2010. Wacana; Kajian Kekuasaan Berdasarkan Ancangan Etnografi Komunikasi dan Pragmatik. Yogyakarta: Pustaka Prisma.

Kridalaksana. 2008. Kamus Linguistik Edisi keempat. Jakarta: Gramedia Pustaka Utama.

Leech, G. 1983. Prinsip-prinsip Pragmatik. Terjemahan oleh Oka, M.D.D. 2011. Jakarta, Universitas Indonesia (UI-Press).

Mahsun. 2007. Metode Penelitian Bahasa: Tahapan strategi, metode, dan tekniknya. Jakarta: PT RajaGrafindo Persada. 
Rani, A. 2004. Analisis Wacana; Sebuah Kajian Bahasa dalam Pemakaian. Malang: Bayumedia Publishings.

Rustono. 1999. Pokok-Pokok Pragmatik. Semarang:IKIP Semarang Press.

Sari, N. N. 2013. "Strategi Personal Branding Joko Widodo (Jokowi) dan Basuki Tjahaja Purnama (Ahok)". Malang: Universitas Brawijaya.

Wikipedia. Gelar Wicara, (online), (https://id.wikipedia.org/wiki/Gelar_wicara.html. diakses 1 April 2016). 